\title{
The Development of a Hitting Practice Tool Model on Woodball
}

\author{
S. M. Fernanda Iragraha \\ Postgraduate Student \\ Universitas Negeri Semarang \\ Semarang, Indonesia \\ fernanda.iragrahasukses33@yahoo.com \\ Soegiyanto K. S. \\ Postgraduate Program \\ Universitas Negeri Semarang \\ Semarang, Indonesia \\ soegiyanto.ks@gmail.com
}

\author{
Sugiharto \\ Postgraduate Program \\ Universitas Negeri Semarang \\ Semarang, Indonesia \\ sugiharto.ikor@mail.unnes.ac.id \\ Hari Setijono \\ Postgraduate Program \\ Universitas Negeri Surabaya \\ Surabaya, Indonesia \\ harisetijono@yahoo.co.id
}

\begin{abstract}
-this research aims to produce working models of hitting practice tools, which can be used as an effective training tool for amateur athletes and also for other woodball lovers in Indonesia. The research and development of this hitting practice tool improve an existing model of Gall, Gall, \& Borg. The research steps include the following : (1) research and collection of information (2) planning; (3) development of preliminary product model; (4) preliminary field testing; (5) revision of main product; (6) testing of main field; (7) revision of operational product; (8) testing of operational field; (9) revision of final product; and (10) dissemination and implementation. Small-scale field trials were conducted at Remaja Bhayangkara Club (RBC), or Bhayangkara Youth Club, Bali. 6 athletes ( 3 boys and 3 girls) participated in the small-scale field trials. Large-scale field trials were conducted at Woodball Buleleng Club (WBC), or Buleleng Woodball Club, Bali, involving 20 athletes (10 boys and 10 girls). The instruments used include interviews, field notes, validation value, scale questionnaires, guidelines on the monitoring/observation of the model for hitting practice tools, guidelines on monitoring/observation of the effectiveness of the models for hitting practice tools, and observation guidance in athletes' response. The research produced the following results: (1) models of tools that can be used to improve the frequency of hitting practice; (2) improvement in the consistency of hitting so as not to exceed 10 seconds (according to the rules of The Indonesian Woodball Association/IWBA); (3) assisting the efficiency of the athletes practice time as athletes can now perform hitting practice repeatedly in one place and in a variety of weather conditions (this tool can be used in the field and in the room); (4) when exerting effort during training, the strength of the athlete can be used more efficiently (since athletes do not need to take the ball into the field after hitting); (5) athletes can learn how to hit the ball easily (because this tool can be used to practice short, medium, long, and finishing hitting); and (6) through this hitting practice tool, it is expected that athletes become more precise and accurate in hitting, so that their performance can be improved. This hitting practice tool model is effective and is fit to be used as a training tool for amateur woodball athletes.
\end{abstract}

Keyword--development, practice, hitting, woodball

\section{INTRODUCTION}

Woodball is a game that can be played on a green field or any suitable arena. It is a sport that can be played by anyone, regardless of age and gender [1]. Woodball is a game that you play against yourself [2]. The phrase 'against yourself,' showcases the philosophy of woodball. Woodball is very different from some other sports, like badminton, volleyball, basketball, table tennis, boxing, and so forth. All the sports listed above require the athlete to beat opponents (sometimes with emotion) any way to win a race or game.

Woodball is a sport whose popularity in Indonesia is increasing daily. An outdoor sports game can be played on a grassy field (woodball) or on the coast (beach woodball). The game is played individually, in pairs, or in a team. The game is played by hitting the ball gradually until the ball enters the goal (gate) that exists in each track (fairway) with a minimum number of blows. The player with the least number of blows is the winner [1].

Woodball is a game modified from golf. It utilizes the concept of basic motion in golf (locomotor, non-locomotor, and manipulative). Woodball also involves efficient use of time, place, and cost. Woodball also involves maintaining the environment and promoting healthy living in humans by encouraging them to participate in sporting activities. According to Iragraha [2], a very interesting thing from woodball is that it contains three basic motion concepts (1) locomotor motion: Woodball involves the act of moving the body from one point to another (the woodball athlete runs from fairway one to the other fairway); (2) non-locomotor motion: Woodball involves bending and swinging mallet movements of the wooden bat; and (3) manipulative motion: Woodball requires coordinating the body, space and objects around it, for example, the movement that occurs when the athlete swings the mallet to hit the ball towards the target or gate.

Some Indonesian woodball athletes have achieved great things and made the nation proud. Ahris Sumariyanto, Indonesia's best male woodball athlete, according to News Letter magazine No. Edition. 17, as ranked the number one in the world in 2012. Ahris Sumariyanto also won a gold medal at the Asian Beach Games 2016 (Danang, Vietnam). In 2016 
and 2017, Ahris Sumariyanto ranked as number one in the world. For any sport, there is a need for organizational coaching and individual coaching for an athlete to excel. Until now, especially for athletes in the adult categories, athletes from Banten Province, Central Java Province, and Bali Province contributed the most outstanding athletes from the national to the international levels. Athletes such as Ahris Sumariyanto, Ahmad Faqih, Ika Yulianingsih, Muhamad Khadiq, I Kadek Agus, and Putu Budhiyasa has achieved a lot as adult (senior) athletes in the national and international arena. But their achievements haven't been replicated by novice athletes (junior). There is a widespread unbalance in the capabilities of woodball athletes, which is caused by focusing training on senior athletes alone. Senior athletes are the only ones sent to participate in various training events. Beginner athletes are underestimated and do not have access to these training facilities. There are limited training facilities and infrastructure in various regions, and amateur athletes do not have access to permanent fields in some of these regions. Most trainers have never thought about using a tool in the training process. There is also a lack of mastery of techniques of playing woodball for most beginner athletes. But there are a few areas that already have permanent fields such as Sleman-Yogyakarta and Buleleng-Bali. Yet, athletes from these areas are yet to have significant achievements in national and international woodball events.

The results of interviews and observations conducted by researchers in Sleman-Yogyakarta Regency and in BulelengBali Regency revealed various problems experienced by beginner athletes, namely: (1) lack of mastery of the techniques of playing woodball (starting from how to hold a bat or mallet, to prepare or to set-up, to swing, when hitting a ball or impact, and during the next movements or follow through; (2) beginner athletes look less confident when hitting the ball and this can be seen from the length of time taken for the athlete to get a hit (often more than 10 seconds). If the hitting takes too much time, the athlete can get penalized according to the IWBA rules. When the impact between the mallet and the ball is hard, the athletes are too slow to turn their head to see the movement of the ball; (3) when beginner athletes hit the ball, and they are watched by their coaches or friends and families, they look nervous, often displaying an expression of shame and it greatly affects the outcome of the hitting); (4) These athletes are hardly able to understand the layout of the playing field (this is indicated by the number of balls that go outside the field track or fairway when the athlete is hitting a bat); (5) the practice sessions of these athletes are ineffective because they use only 1 (one) ball for hitting practices; and (6) there are no tools that can be used to facilitate the woodball training process in both districts. Based on the problems mentioned above, a variety of efforts need to be done by researchers to develop an effective training process and improve efficiency (in terms of time, effort and cost) for beginner athletes. Researchers developed a hitting practice tool for beginner athletes in woodball sports. There was a swing trainer tool developed by Anas Kholikul Amin [3]. The study produced woodball training tools that can be used for swinging practices for both beginner and advanced level woodball male athletes. The previous training tool developed looks bulky. The tool is too large, which makes it difficult to move to other places. In addition, many woodball athletes could not use it, and it could not be mass-produced. In addition, it is less effective to use for training, because the tool was only developed for swinging skills not for hitting the ball like in real games.

The ineffectiveness of the tools that have been developed before makes it necessary for researchers to innovate and develop a model of hitting practice tool that is perfect for beginner athletes in woodball. The development of this training tool is expected to have a significant impact on the training process (both in the field and out of the field). The purpose of this study is to produce a model of a hitting practice tool that is effective and feasible to use for beginner athletes in woodball.

\section{METHOD}

This research uses research and development methods to develop and hitting practice tools for use in woodball. This research project was mandated based on explanation from Gall, Gall, \& Borg that research and development is an industry-based development model in which the findings of research are used to design new products and procedures, which are then systematically field-tested, evaluated, and refined until they meet specified criteria of effectiveness, quality, or similar standards [4]. Maksum states that development research is a type of research that aims to develop a new product or perfect an existing product. Research and development are research methods used to produce certain products and test the effectiveness of these products [5].

The research and development of hitting practice tools for beginner athletes in woodball were carried out through several steps adapted from the model approach system designed by Gall, Gall, \& Borg. The steps of the research and development model of Gall, Gall, \& Borg consist of ten steps, namely: (1) research and information collecting; (2) planning; (3) developing the preliminary of the product; (4) preliminary field testing; (5) main product revision; (6) main field test; (7) operational product revision; (8) operational field testing; and (9) final product revision; and (10) dissemination and implementation [4].

The data analysis techniques carried out in this study were quantitative descriptive analysis and qualitative descriptive analysis. Quantitative descriptive analysis was conducted to analyze the data: (a) draft of validation value scale questionnaire tool development model; (b) instruments for observing the tool development models; (c) instruments for observing the effectiveness of the tool development model; and (d) instruments for observing athletes' responses. While the qualitative descriptive analysis was in the form of an instrument for suggestions concerning improvements from material experts, media experts, and sports practitioners as well as field notes obtained before the field trials and after field trials of the developed hitting practices tool. 
Advances in Social Science, Education and Htmanities Resgarfh yolume 278 items of validation results

\section{RESULTS}

A. The Product Description of the Hitting Practice Tool Model

This developed tool is intended for beginner athletes in woodball. The specifications of this equipment are as follows: (1)A carpet; (2) A swinger ball; (3) A box of iron and triplex board (length of $100 \mathrm{~cm}$, height of $3 \mathrm{~cm}$, and width of $80 \mathrm{~cm}$ ), and weight of the tool $\pm 10 \mathrm{~kg}$. The use of this hitting practice tool is very simple. First, the athlete stands on the carpet and then prepares the hitting training position to be practiced (short hit, medium hit, long hit, and gatting/finishing), then the athlete starts to practice hitting with the tool. The following is a picture of a hitting practice tool.

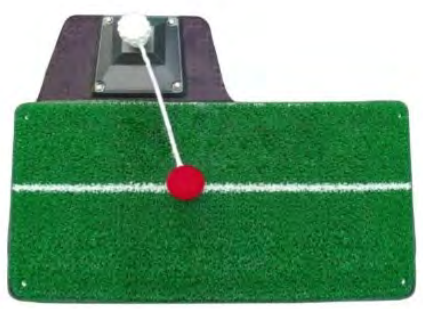

Fig 1. The Hitting Practice Tool Model

\section{B. The Results of Expert Validation and The Test of} The Effectiveness of The Hitting Practice Tool from material experts, media experts, and sports practitioners, as well as 10 classification items from observations of the effectiveness in the value scale of material experts, practitioners, and responses to the hitting practice tool model for beginner athletes in woodball sports.

TABLE I. VAlidation Results From MATERIAL, MEDia EXPERTs, AND PRACTITIONER

\begin{tabular}{|c|c|c|c|c|c|c|c|c|c|c|c|c|}
\hline \multirow{3}{*}{$\begin{array}{c}\text { Valida- } \\
\text { tion } \\
\text { Code }\end{array}$} & \multirow{3}{*}{$\begin{array}{c}\text { Experts } \\
\text { Code }\end{array}$} & \multicolumn{10}{|c|}{ Classification Items } & \multirow{3}{*}{$\mathbf{N}$} \\
\hline & & 1 & 2 & 3 & 4 & 5 & 6 & 7 & 8 & 9 & 10 & \\
\hline & & \multicolumn{10}{|c|}{ Assessment Results of Value Scale } & \\
\hline \multirow{4}{*}{ H1 } & A1 & 3 & 4 & 4 & 4 & 4 & 3 & 3 & 4 & 4 & 4 & 37 \\
\hline & $\mathrm{A} 2$ & 3 & 4 & 4 & 4 & 4 & 4 & 4 & 4 & 4 & 3 & 38 \\
\hline & A3 & 3 & 3 & 4 & 4 & 4 & 4 & 3 & 4 & 4 & 3 & 36 \\
\hline & P1 & 3 & 3 & 4 & 4 & 4 & 4 & 3 & 4 & 4 & 3 & 36 \\
\hline
\end{tabular}

TABLE II. ASSESMENT OF MATERIAL, MEDIA EXPERTS, AND PRACTITIONER

\begin{tabular}{|c|c|c|}
\hline \multirow{2}{*}{ Category } & \multicolumn{2}{|c|}{ H1 } \\
\cline { 2 - 3 } & F & \% \\
\hline Lack & 0 & 0 \\
\hline Fair & 0 & 0 \\
\hline Good & 4 & 100 \\
\hline Total & 4 & 100 \\
\hline
\end{tabular}

TABLE III. OBSERVATION RESULTS OF PRACTCE TOOL

\begin{tabular}{|c|c|c|c|c|c|c|c|c|c|c|c|c|}
\hline \multirow{3}{*}{ Validation Code } & \multirow{3}{*}{$\begin{array}{l}\text { Experts } \\
\text { Code }\end{array}$} & \multicolumn{10}{|c|}{ Classification Items } & \multirow{3}{*}{$\mathbf{N}$} \\
\hline & & 1 & 2 & 3 & 4 & 5 & 6 & 7 & 8 & 9 & 10 & \\
\hline & & \multicolumn{10}{|c|}{ Assessment Results of Value Scale } & \\
\hline \multirow{4}{*}{$\mathrm{H} 2$} & $\mathrm{~A} 1$ & 4 & 4 & 3 & 4 & 3 & 3 & 4 & 4 & 4 & 4 & 37 \\
\hline & A2 & 4 & 4 & 3 & 4 & 3 & 4 & 4 & 4 & 3 & 4 & 37 \\
\hline & $\mathrm{P} 1$ & 4 & 4 & 3 & 4 & 3 & 3 & 4 & 4 & 3 & 4 & 36 \\
\hline & $\mathrm{R} 1$ & 3 & 4 & 4 & 4 & 4 & 3 & 3 & 4 & 4 & 4 & 37 \\
\hline
\end{tabular}

TABLE IV. EFFECTIVENESS OF HIITING PRACTICE TOOL

\begin{tabular}{|c|c|c|}
\hline Category & F & \% \\
\hline Less effective & 0 & 0 \\
\hline Fairly Effective & 0 & 0 \\
\hline Effective & 3 & 100 \\
\hline
\end{tabular}

\section{DISCUSSION}

Woodball is a game played against yourself. The phrase 'against yourself' is a philosophy of woodball. Woodball is very different from other sports, like badminton, volleyball, basketball, table tennis, boxing, and so on. All the sports mentioned above require athletes to beat opponents, while in woodball you are to beat yourself and not your opponents. Woodball is a sport that involves playing softly into oneself and playing against oneself A woodball player cannot defeat an opponent by being emotional and hitting the ball as strong as possible. The uniqueness of woodball is that this game relies on strategy or self-management. So, when a woodball player has good strategies and good self-management, he will produce a precise punch (the ball must continue in the fairway when it is hit) with good accuracy (the hitting when gating the ball must go through the small goal). When a woodball player relies on emotions and hit the ball as hard as possible without control, finesse and precision, it is hard to get an accurate hit.

A woodball game is best enjoyed when watching a player that displays good strategy and player management. A player must decide whether to take a number of shots to enter the ball into the gate (small goal) or to do the gating execution directly. Woodball is directly related to the values of everyday life. For example, when completing a task, how many steps are necessary to complete the task? A woodball game can reflect the character of persons and they work in their daily life. The woodball game can show if a person is an emotional person, a risk taker, a calculative person, or someone who implements good strategies and long-term planning in making decisions.

Based on the findings of the above research, this study (1) produced a model of a hitting practice tool that can be used to increase the frequency of hitting practices; (2) increased the consistency of punches can be improved to not exceed 10 seconds (according to the rules of The Indonesia Woodball 

repeatedly in one place and in various weather conditions (this tool can be used in the field or indoors); (4) ensured that athletes are more efficient when exercising and exert less energy (because after hitting, an athlete it is not necessary to take the ball into the field); (5) ensured that athletes learn how to hit the ball easily (because the tool can be used to practice short, medium, long, and finishing punches); and (6) through this hitting training tool, it is expected that the athlete's punch will become more precise and accurate, so that his performance can be increased.

The limitations of this study are, (1) the hitting practice training tool model developed by researchers is intended for beginner athletes alone; (2) this tool does not implement technology (it only uses manual methods and practice tests); and (3) the development of this practice aid is limited to the results of manual products, so there is a need for further development.

\section{CONCLUSION}

This study produced a hitting practice tool product for beginner athletes in woodball. The product is named "Wood Practice". Based on the results of the above research, it can be concluded that: (1) the product model of the hitting practice tools "Wood Practice" is effective and is suitable for use as a training tool for beginner athletes; (2) can be used to improve the frequency of hitting practices; (3) can be used to improve hitting consistency; (4) improve training time

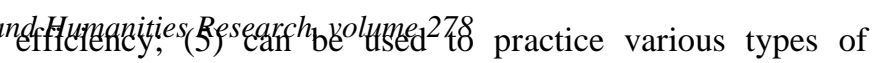
punches; and (6) as a means of developing technical skills of woodball athletes.

In conclusion, it is hoped that this study produces athletes that will train with these products. Through the results of this study, it is expected that readers, trainers, athletes, and administrators of woodball sports organizations can find out about the training product and use the product for both indoor and outdoor training. It is hoped that this tool will transform the Indonesian sporting industry.

\section{REFERENCES}

[1] A.K. Amin, M. Doewes, S.K. Purnama, 2017. "Development of Prototype: A Swinging Training Aid Tool (Swing Trainer) on Woodball Male Athletes". European Journal of Physical Education and Sport Science, 2017, vol. 3, no. 4.

[2] M.D. Gall, Gall, J.P., W.R. Borg, "Educational Research: an Introduction ( $8^{\text {th }}$ ed.)". New York: Pearson Education, Inc, 2007.

[3] International Woodball Federation, "About IWbF: Philosophy; Courses; Equipment; Woodball rules and etc". Retrived from http://www.iwbf-woodball.org/en/1-2.php, 2014.

[4] S.M.F. Iragraha, "The Existence of Woodball Athletes Coaching at the Student Activity Unit (UKM) Semarang State University". The 4th International Conference on Physical Education, Sport and Health (ISMINA) and Workshop: Enhancing Sport, Physicalactivity, and Health PromotionFor a Better Quality of Life, 2017, pp. 885-892

[5] A. Maksum, "Metodologi Penelitian dalam Olahraga". Surabaya: Unesa University Press, 2012 